\title{
Enzymatic hydrolysis as an approach to produce alternative protein from cephalopods ink powder: a short review
}

\author{
Ayu Shazwani, Z. and *Rabeta, M.S. \\ Food Technology Division, School of Industrial Technology, Universiti Sains Malaysia, 11800 Penang
}

\begin{abstract}
Article history:
Received: 28 December 2019

Received in revised form: 18

February 2020

Accepted: 21 February 2020

Available Online: 27 March

2020
\end{abstract}

Keywords:

Hydrolysis,

Squid ink powder,

Cuttlefish ink powder,

Alternative protein

\section{DOI:}

https://doi.org/10.26656/fr.2017.4(5).423

\begin{abstract}
Cephalopoda is a class of Mollusca that lives in marine environments, well-known as the most distinctive features of their ink especially squid and cuttlefish species. The various valuable constituents in their ink have been used over millennia for practical and commercial purposes. The current world population of 7.6 billion is expected to reach 8.6 billion in 2030, 9.8 billion in 2050, and 11.2 billion in 2100 . Thus, the amount of food, types of food in demand, and their relative contribution to diets will all change. We may face a reduction in protein sources worldwide. Humans need protein in their daily diet to maintain good health. To date, information on the benefits of squid and cuttlefish ink hydrolysates in Malaysia as an alternative protein is lacking. This study aims to review this gap and propose the potential of squid and cuttlefish ink hydrolysates as an alternative protein.
\end{abstract}

\section{Introduction}

Cephalopoda belong to the Phylum Mollusca includes animals with soft-bodied, and bilaterally symmetrical, Nautiloidea (nautilus) and Coleoidea are two major groups that represent cephalopods in which squids, cuttlefish, nautilus and octopus are included (Nair et al., 2011; Derby, 2014). The number of species of cephalopods is relatively low (about 700), but they are widely distributed in different marine oceanic habits (Derby, 2014). Cephalopods have become valuable commercial fishery resource worldwide as Thailand recorded the largest exporter, followed by other Southeast Asian countries (Hoque et al., 2010). For a long history, especially Greek and Egyptians have been used cephalopod meat, even in the broader application of foods (Sundaram, 2009). Squid and cuttlefish have become an important fishery product in Southeast Asian countries and are exported worldwide (Food and Agriculture Organization of the United Nations, 2018).

Visceral organs included ink sac are the major byproducts discarded and generated during the processing of cuttlefish and squid, consequently, offer an enormous crisis of ecological and environmental pollution (Vate and Benjakul, 2013). Numerous researchers demonstrated interest in comparative studies of melanogenesis in squid ink (Wang et al., 2019). Melanogenesis is the reaction of melanin pigment produced dark color of squid and cuttlefish ink which occurred in the presence of melanogenic enzyme such as tyrosinase, dopachrome rearranging enzyme and peroxidase ( Jiménez-Cervantes et al., 1994; Ahamed et al., 2018). The darker color of black pigment in squid ink is affected by the number of enzymes presents that allow more melanin (Palumbo, 2003). Besides blackened by melanin, it is rich with proteins, lipids, glycosaminoglycans, enzymes, various minerals and metals such as copper, cadmium and lead (Mimura et al., 1982; Zhong et al., 2009). The presence of large amounts of amino acids revealed from the crude melanin of squid ink included glycine, glutamic acid and aspartic acid, as well as a trace of sulfur, contained amino acids through the chemical analysis process (Mimura et al., 1982).

Among of these by-products, it has been utilized as a source of bioactive compounds that have been used in a vast scale as alternative medicine and therapeutic properties (McConnell et al., 1994; Nair et al., 2011; Vate and Benjakul, 2013). According to Sasaki et al. (1997), cephalopods ink is a by-product that commonly utilized as a food additive for application in food processing. Cephalopod ink historically has been used to promote human health and has been contributed in traditional medicine application for Eastern culture in China while in Western for ancient Greece and Rome (Zhong et al., 2009; Nair et al., 2011; Derby, 2014). Traditionally in Japan, squid ink is used to preserve food 
products, as 'Ika-shiokara', a cured cuttlefish meat extended the shelf-life when treated with cuttlefish ink as believed exhibits antiseptic (Takai et al., 1993; Sasaki, 1997). In Malaysia, especially in eastern peninsular, squid ink is purposely mixed in dishes to rise the flavor (Ahamed et al., 2018). The squid ink has been affected the growing performance of broiler chicken, besides having an antioxidant and immunity functions (Liu et al., 2011). Cephalopods ink is found to consist of natural antioxidant value in melanin and melanin-free components (Derby, 2014). Hence, the utilization of these by-products helps in lessening pollution threats, disposal problem and indirectly benefit the processing industry (McConnell et al., 1993; Lian, 2005). It is welldocumented of cephalopods waste materials are multifunctional marine sources that have been revealed their various beneficial properties. In this review, future cephalopods ink was analysed to be considered as an alternative protein.

\section{Constituents of Cephalopods ink}

Cephalopod species, such as squid and cuttlefish, release a dark cloudy ink from their sacs as an adaptive response when confronted with danger and physical threats (Lei et al., 2007; Liu, 2011). Squid and cuttlefish defend themselves by camouflaging to match their surroundings, escaping from enemies, and giving a signal to others (Lucero et al., 1994; Derby, 2014; Nicomrat and Tharajak, 2015). The ink sac lumen stores the ink gland, which immediately secrets ink to the hindgut via a duct alongside the anus (Derby, 2014). In addition, their muscular walls and sphincters are highly specialized to control the ejection of ink from the sac. While, glutamate, nitric oxide and cGMP help in regulated of ink production by activating the pathway to increase the tyrosinase and production of melanin pigments (Palumbo et al., 1997; Palumbo et al., 2000; Derby, 2014).

Researchers discovered that squid ink mainly consists of suspensions of melanin granules and protein polysaccharide complexes which are located at the bottom of the sac and are created in the mature cells of the ink gland (Liu et al., 2011; Nair et al., 2011). Variant melanogenic enzymes, such as tyrosinases, peroxidases, and dopachrome-rearranging enzymes, are found in ink glands (Palumbo et al., 1998; Derby, 2014). Peroxidase in the later stages of melanin biosynthesis and promotes the formation of eumelanin polymers from monomers. All factors participating in melanin formation, such as hydrogen peroxide, enzymes, starting products, and intermediates, are present during melanogenesis (d'Ischia et al., 1991).

\section{Enzymatic hydrolysis}

Squid and cuttlefish ink, which are waste products in the processing industry, may be used to prepare protein hydrolysates through hydrolysis by different enzymes. Kechaou et al. (2009) reported the enzyme and substrate used are affected the total amino acid obtained. The enzymatic method seems the best at recovering bioactive materials compared to chemical or physical methods and microbial fermentation (Wang et al., 2019). Particularly, the application of hydrolysate helps in developing a new functional food where it allows the production of small peptides and amino acids that enhanced the flavor properties (Su et al., 2012). Lian et al. (2015) discovered squid by-products expressed the highest level of protein for the generation of peptides and free amino acids through proteolytic hydrolysis. The enzymatic hydrolysis process of by-products is a widely applied for improvement of protein properties (Baek and Cadwallader, 1995; Liaset et al., 2000; Nielsang et al., 2005; Jae-Young et al., 2007; González-félix et al., 2014)

In addition, enzymatic hydrolysis is an important role for digestibility activity (Panyam and Kilara, 1996). Fish protein hydrolysates have been well studied in terms of production, biochemical, and functional properties (Kristinsson and Rasco, 2000). Quaglia and Orban (1990) supported the enzymatic treatment improved the functional characteristics under controlled condition. It is believed to increase levels of essential amino acids and well-define the functional as well as the nutritional value of hydrolysates, regardless of the protease used (Kechaou et al., 2009). The crude ink extracts from cephalopods species have been working on its various functional values such as amino acid composition, solubility, stability, emulsifying and many other properties (Zayas, 1997a; Zayas, 1997b; Ian and Ee, 2005; Kechaou et al., 2009; Derby, 2014).

\section{Physicochemical properties of cephalopod ink}

\subsection{Chemical composition}

Crude ink extracts of squid (Loligo duvauceli) reported consisting high amount of protein, followed by the mineral, moisture and fat content (Fatimah Zaharah and Rabeta, 2017). Okuzumi and Fuiji (2000) revealed the squid is considered high protein as the main constituent is $80 \%$ of myofibrillar protein, $12-20 \%$ of myoplastic protein and $2-3 \%$ of myostroma protein, whereas mineral content differed depending on maturity, biological stage, habitat, species also affected by the concentration of the mineral in seawater. Liu et al. (2011) reported cuttlefish (Sepialla maindroni) ink is an intermixture, and its primary components are protein 
polysaccharide complexes that consist of 16 amino acids, high aspartic acid content, and nine fatty acids (approximately $1.34 \%$ ) constituted by $43.4 \%$ and $56.6 \%$ of unsaturated and saturated ones, respectively. Calcium is the most common mineral element found in cephalopods ink (Takaya et al., 1994; Chen, 2000; Zheng et al., 2002; Liu et al., 2011). The minerals present in melanin substances is generally implicated in the maintenance of normal metabolic and physiological functions and are important components of enzymes and structural proteins (Neifar et al., 2009).

Neifar et al. (2009) worked on cuttlefish (Sepia offinalis) specimens found out the melanin is composed of carbohydrates polymer and proteins and concluded the crude ink is higher crude protein. Sepia melanin is an oligomeric structure that contains $75 \%$ 5,6dihydroxyindole 2-carboxylic acid (DHICA) derived units and 20\% 5,6-dihydroxyindole (DHI) derived units, which are mostly degraded to pyrrole-2,3-dicarboxylic acid and pyrrole-2,3,5-tricarboxylic acid, respectively. The peptide fragments found in melanin are called melano-proteins (Knicker et al., 1995; Pezzella et al., 1997). The glycosaminoglycans in melanin include polysaccharides (Chen et al., 2010), tyrosinase (Naraoka et al., 2003) and angiotensin-converting enzyme inhibitor (Kim et al., 2003) and exhibit strong free radical protection activity (Menon and Haberman, 1977).

The Boreo Pacific gonate (Gonatopsis borealis) squid ink discovered to contain high amounts of protein compared to other squid species, such as neon flying (Ommastreohes bartrami) and boreal club-hook (Onychoteuthis borealijaponica). All three inks also contain high amounts of carbohydrate and have been traced for large amounts of homarine and glycine betaine, rich of taurine and hydroxyproline and contain the least amount of trimethylamine oxide (Shirai et al., 1997). The presence of high molecular weight sugars is reported in squid ink (Matsue et al., 1995). Derby (2014) reported cephalopod ink is rich in dissolved free amino acids. Six species of cephalopods, including squid (Doryteuthis (Loligo) pealeii, Lolliguncula brevis), octopus (Octopus vulgaris, Octopus bimaculoides) and cuttlefish (Sepia officinalis), contain total dissolved free amino acids ranging from $0.5 \mathrm{mM}$ to $132 \mathrm{mM}$. The ink from five out of these six species contains $50 \%$ or more taurine and glutamate ranging from $3 \%$ to $7 \%$. Approximately $0 \%$ to $2 \%$ of the total dissolved free amino acids contain $0 \mathrm{mM}$ to $2.9 \mathrm{mM}$ tyrosinase (Derby et al., 2007).

Mimura et al. (1982) revealed crude melanin of squids (Ommastrephes bartrami) known as a melanoprotein, composed a large amount of melanin pigment, protein and carbohydrate and detected several amounts of amino acids such as glycine, aspartic acid and glutamic acid. The documented evident through the major species of cuttlefish which are Sepia pharaonis, $S$. prabahari and S. ramanias found the presence of protein quite lower compared to other crustacean is commonly ranged between $12.59 \%$ to $16.47 \%$. The constituted of ash and carbohydrates, particularly is less than $3 \%$, whereas fat content stated for cuttlefish species is ranged between $0.19 \%$ to $0.21 \%$ (Ganesan et al., 2017). LopezGonzalez et al. (2003), also reported the similar results of proteins, minerals, fats and carbohydrates in the dried squid ink sample. The squid (Loligo duvauceli) ink found out protein is higher followed by carbohydrate are estimated by Folin-Ciocalteu reagent and Anthrone method, respectively (Nisha and Suja, 2018). The presence of functional properties such as the composition of amino acids, and environmental factors includes temperature, $\mathrm{pH}$ and ions affected the ability of protein as a food ingredient (Geirsdottir et al., 2011). Various species of cephalopods ink has been studying their proximate analysis, which is represented in Table 1. Protein is a prominent and significant compound discovered due to the higher percentage followed by the amount of fat, carbohydrate, and ash in different kinds of ink sample. Protein hydrolysate with lower fat content helps in improving the stability of products (Nilsang et al., 2005). In terms of protein content, several researchers have been reported the similar results different fish and degrees of hydrolysate (Kristinsson and Rasco, 2000; Gbogouri et al., 2004).

\subsection{Solubility}

Good solubility is one of the most important functional properties of protein hydrolysates (Sila et al., 2014), which directly affected the properties of emulsification and foaming (Kristinsson and Rasco, 2000). Ahamed et al. (2018) have been performed water solubility index (WSI) of Indian squid (Loligo duvauceli) and cuttlefish (Sepia latimanus) ink powders and the results showed $17.12 \%$ and $10.51 \%$, respectively which are considered high. Jeyasanta and Patterson (2020) also reported squid (Loligo duvauceli) ink powder showed a WSI of $16.8 \%$. A high WSI value indicates good dispersibility of protein molecules, resulting in fine dispersion and formation of colloidal systems (Zayas, 1997a). Protein solubility is affected by $\mathrm{pH}$, solvent type, ionic strength, temperature, and processing conditions. This parameter increases when the electrostatic repulsion between molecules is higher than the hydrophobic interaction (Zayas, 1997b).

In terms of $\mathrm{pH}$ factor, hydrolysates showed low solubility at the isoelectric points in weak acidic 
condition. These solubility variations attributed to both peptides net charges, $\mathrm{pH}$ moves away from the $\mathrm{pI}$ as increases, in the other hand, the surface hydrophobicity encourages aggregation via hydrophobic interaction (Sorgentini and Wagner, 2002). The improvement of protein solubility by enzymatic hydrolysis could be an effective alternative as promotes the soluble peptide release (Sila et al., 2014). Klompong et al. (2007) studied the protein degradation to smaller peptides contributes more soluble products. Jridi et al. (2014) suggested the solubility increase in protein hydrolysates due to the enzymatic reaction release of smaller polypeptide units thus reduce the molecular size of peptides. Moreover, lower of molecular size peptides produces through enzymatic treatment showed more hydrophilic and solvated in aqueous solution (Li et at., 2013). The ability of smaller peptides to form hydrogen bonds with water is presumed to have proportionally more polar residues and consequently increase solubility (Gbogouri et al., 2004).

\subsection{Emulsification}

Kinsella (1976) reported protein helps in forming and stabilizing food emulsion. Cuttlefish (Sepia latimanus) and squid (Loligo duvauceli) are reported higher of emulsifying activity and stability. The emulsion activity showed the highest mean value of 15.38 and 11.88 , whereas emulsion stability showed higher mean value of $56.56 \%$ and $39.09 \%$ for cuttlefish and squid inks, respectively. The value is different due to the difference in their protein contents, hence cuttlefish and squid ink presented good emulsifying properties (Ahamed et al., 2018). The emulsion stability value is based on the electrostatic repulsion between protein molecules. This result discovered these inks showed good stability against flocculation and droplet coalescence. Decreasing particle size is dependent on the attractive forces acting between the droplets, whereas the particle size slightly affected the steric repulsion range (Qian and McClements, 2011).

Protein hydrolysates are surface active and promote oil-in-water emulsions as comprised of hydrophilic and hydrophobic components (Wilding et al., 1984). The emulsifying properties of hydrolysate related to the peptide effectiveness in lessening interfacial tension between hydrophobic and hydrolytic elements in food (dos Santos et al., 2011). Many factors accounted for the value of Emulsion stability index (ESI) and one of the reasons might be due to different $\mathrm{pH}$ levels during hydrolysis (Baharuddin et al., 2016). Increasing of negative charge peptides present in highly alkaline condition contributes to more unfolding polypeptides. As more exposure of hydrophilic and hydrophobic peptide residue, more interactions at the oil-water interface (Taheri et al., 2013).

\subsection{Other properties of cephalopods ink}

Indian squid (Loligo duvauceli) and cuttlefish (Sepia latimanus) ink have been evaluated the essential part of the powder flow evaluation, which is the bulk and tapped density and found out both possess of higher bulk and tapped density (Ahamed et al., 2018). The powder bulking property directly related to several factors such as preparation, treatment and storage of the sample (World Health Organization, 2012). Raftani Amiri et al. (2016) revealed the foaming activity index (FAI) and foaming stability index (FSI) of cuttlefish (Sepia pharaonis) hydrolysates showed cuttlefish protein hydrolysates (CPHs) muscle prepared by protamex (CPHP) had higher FAI and FSI than alcalase (CPHA), while the foaming properties reduced at the acidic condition which is $\mathrm{pH}$ 4. The higher of FAI and FSI obtained, it is considered to have the ability as foaming agent that can be used in food applications. The $\mathrm{pH}$ indicates major effect towards foam stability as it might be decreased at acidic $\mathrm{pH}$ due to the repulsion of peptides (Klompong et al., 2007; Elavarasan et al., 2014).

Ahamed et al. (2018), also studied the properties of water activity $\left(\mathrm{a}_{\mathrm{w}}\right)$ of squid (Loligo duvauceli) and cuttlefish (Sepia latimanus) ink powder and the results are relatively low which below 0.2 . The pathogen growth is stated over 0.98 and the food products have lower $\mathrm{a}_{\mathrm{w}}$ are considered safe (Lund et al., 2000). The $\mathrm{a}_{\mathrm{w}}$ for dry food in the range 0 to 1 and moist food is 0.99 , whereas the optimum $a_{w}$ promotes the stability and life span of products under ambient storage. The criteria of squid and cuttlefish ink mostly satisfy the industrial needs, where it has presented lower $a_{w}$, higher tapped density, good oil absorption capacity, foaming ability, water solubility and emulsifying ability (Ahamed et al., 2018). Thus, all these factors contribute to rising interest among researchers in recent years.

\section{Conclusion}

Among the marine waste materials, cephalopod ink is one of the potential sources of natural bioactive product because of its fewer side effects compared to synthetic sources. Several studies proved that the information on functional characteristics in various modes of application satisfies the needs of the industry. This review summarizes the potential cephalopods ink, particularly its component, physical and functional properties as an alternative protein. Cephalopod ink is biochemically rich in proteins, minerals, lipids and carbohydrates, however, information on this material 
especially its functional characteristics remains scarce. Although squid ink has been studied for many years, especially in pharmacology, their wastes are still discarded and generated. Thus, understanding their valuable origin and providing an opportunity for further utilization might be a meaningful work that may lead to the reuse and reduction of marine waste.

\section{Conflict of Interest}

The authors declare no conflict of interest.

\section{Acknowledgments}

This study was financially supported by Bridging Grant with grant number 6316287 obtained from Universiti Sains Malaysia.

\section{References}

Ahamed, A.R.G.B., Hossain, M.P., Antora, R.A. and Rabeta M.S. (2018). Physical and functional properties of Indian squid (Loligo duvauceli) and cuttlefish (Sepia latimanus) ink powder. Food Research, 2(4), 314-319. https://doi.org/https:// doi.org/10.26656/fr.2017.2(4).070

Baharuddin, N.A., Halim, N.R.A. and Sarbon, N.M. (2016). Effect of degree of hydrolysis (DH) on the functional properties and angiotensin I-converting enzyme (ACE) inhibitory activity of eel (Monopterus sp.) protein hydrolysate. International Food Research Journal, 23(4), 1424-1431.

Baek, H.H. and Cadwallader, K.R. (1995). Enzymatic hydrolysis of crayfish processing by-products. Journal of Food Science, 60(5), 929-935. http:// dx.doi.org/10.1111/j.1365-2621.1995.tb06264.x

Chen, X.E. (2000). Study on nutritional composition of Sepialla maindroni ink. Journal of Zhejiang Ocean University, 19(4), 324-326.

Chen, S., Wang, J., Xue, C., Li, H., Sun, B., Xue, Y. and Chai, W. (2010). Sulfation of a squid ink polysaccharide and its inhibitory effect on tumor cell metastasis. Carbohydrate Polymer, 81(3), 560-566. https://doi.org/10.1016/j.carbpol.2010.03.009

Derby, C.D. (2014). Cephalopod ink: production, chemistry, functions and applications. Marine Dugs, 12(5), 2700-2730. https://doi.org/10.3390/ md12052700

Derby, C.D., Kicklighter, C.E., Johnson, P.M. and Zhang, X. (2007). Chemical composition of inks of diverse marine molluscs suggests convergent chemical defenses. Journal of Chemical Ecology, 33, 1105-1113. https://doi.org/10.1007/s10886-0079279-0 dos Santos, S.D., Martins, V.G., Salas-Mellado, M. and Prentice, C. (2011). Evaluation of functional properties in protein hydrolysates from bluewing searobin (Prionotus punctatus) obtained with different microbial enzymes. Food Bioprocess Technology, 4, 1399-1406. https://doi.org/10.1007/ s11947-009-0301-0

d'Ischia, M., Napolitano, A. and Prota, G. (1991). Peroxidase as an alternative to tyrosinase in the oxidative polymerization of 5,6-dihydroxyindoles to melanin(s). Biochimica et Biophysica Acta, 1073(2), 423-430. https://doi.org/10.1016/0304-4165(91) 90152-7

Elavarasan, K., Naveen, K.V. and Shamasundar, B.A. (2014). Antioxidant and functional properties of fish protein hydrolysates from fresh water carp (Catla catla) as influenced by nature enzyme. Journal of Food Processing and Preservation, 38(3), 12071214. https://doi.org/10.1111/jfpp.12081

Fatimah Zaharah, M.Y. and Rabeta M.S. (2017). Antioxidant and antimicrobial activities of squid ink powder Fatimah. International Journal of Current Microbiology and Applied Sciences, 3(4), 904-911.

Food and Agriculture Organization of United Nations. (2018). The state of world fisheries and aquaculture. Rome: FAO.

Ganesan, P.A.B.N., Kanaga, V. and Velayutham, P. (2017). Proximate analysis of cuttlefish ink procured from Thoothukudi coast: A comparative study. International Journal of Fisheries and Aquatic Studies, 5(3), 253-255.

Gbogouri, G.A., Linder, M., Fanni, J. and Parmentier, M. (2004). Influence of hydrolysis degree on the functional properties of salmon byproduct hydrolysates. Journal of Food Science, 69(8), 615622. https://doi.org/10.1111/j.13652621.2004.tb09909.x

Geirsdottir, M., Sigurgisladottir, S., Hamaguchi, P.Y., Thorkelsson, G., Johannsson, R., Kristinsson, H.G. and Kristjansson, M.M. (2011). Enzymatic hydrolysis of blue whiting (Micromesistius poutassou); functional and bioactive properties. Journal of Food Science, 76(1), C14-C20. https:// doi.org/10.1111/j.1750-3841.2010.01877.x

González-félix, M.L., Perez-velazquez, M., Ezquerrabrauer, J.M., Bringas-alvarado, L., Sánchez-sánchez, A. and Torres-arreola, W. (2014). Evaluation of jumbo squid (Dosidicus gigas) byproduct hydrolysates obtained by acid-enzymatic hydrolysis and by autohydrolysis in practical diets for Pacific white shrimp (Litopenaeus vannamei). Food Science and Technology, 34(3), 552-558. https:// doi.org/10.1590/1678-457x.6414 
Hoque, M.S., Benjakul, S. and Prodpran, T. (2010). Effect of heat treatment of film-forming solution on the properties of film from cuttlefish (Sepia pharaonis) skin gelatin. Journal of Food Engineering, 96(1), 66-73. https://doi.org/10.1016/ j.jfoodeng.2009.06.046

Ian, P.Z.L. and Ee, C.M.L. (2005). Characterization of Squid-Processing Byproduct Hydrolysate and Its Potential as Aquaculture Feed Ingredient. Journal of Agricultural and Food Chemistry, 53(14), 55875592. https://doi.org/10.1021/jf050402w

Jae-Young, J., Zhong-JI, Q., Hee-Guk, B. and Se-Kwon, K. (2007). Purification and characterization of an antioxidant peptide from tuna backbone protein by enzymatic hydrolysis. Process Biochemistry, 42(5), 840-846.

j.procbio.2007.02.006

Jeyasanta, I. and Patterson, J. (2020). Bioactive Properties of Ink Gland Extract from Squid Loligo duvauceli. Ecologia, 10(1), 9-19. https:// doi.org/10.3923/ecologia.2020.9.19

Jiménez-Cervantes, C., Solano, F., Kobayashi, T., Urabe, K., Hearing, V.J., Lozano, J.A. and García-Borron, C. (1994). A New Enzymatic Function in the Melanogenic Pathway. The Journal of Biological Chemist, 269(27), 17993-18001.

Jridi, M., Lassoued, I., Nasri, R., Ayadi, M.A., Nasri, M. and Souissi, N. (2014). Characterization and potential use of cuttlefish skin gelatin hydrolysates prepared by different microbial proteases. BioMed Research International, 2014, 461728. https:// doi.org/10.1155/2014/461728

Kechaou, E.S., Dumay, J., Donnay-moreno, C. and Jaouen, P. (2009). Enzymatic hydrolysis of cuttlefish (Sepia officinalis) and sardine (Sardina pilchardus) viscera using commercial proteases : Effects on lipid distribution and amino acid composition. Journal of Bioscience and Bioengineering, 107(2), 158-164. https://doi.org/10.1016/j.jbiosc.2008.10.018

Klompong, V., Benjakul, S., Kantachote, D. and Shahidi, F. (2007). Antioxidative activity and functional properties of protein hydrolysate of yellow stripe trevally (Selaroides leptolepis) as influenced by the degree of hydrolysis and degree type. Food Chemistry, 102(4), 1317-1327. https:// doi.org/10.1016/j.foodchem.2006.07.016

Kim, S.Y., Kim, S.H. and Song, K.B. (2003). Characterization of an partial purification and angiotensin-converting enzyme inhibitor from squid ink. Journal of Agricultural Chemistry and Biotechnology, 46, 122-123.
Kinsella, J.E. (1976). Functional properties of protein in foods: a survey. CRC Critical Review in Food Science and Nitrition, 7(3), 43-81. https:// doi.org/10.1080/10408397609527208

Knicker, H., Almendros, G., González-Vila, F.J., Lu"demann, H.D. and Martin, F. (1995) C13 and N15 NMR analysis of some fungal melanins in comparison with soil organic matter. Organic Geochemistry, 23(11-12), 1023-1028. https:// doi.org/10.1016/0146-6380(95)00094-1

Kristinsson, H.G. and Rasco, B.A. (2000). Fish protein hydrolysates: Production, biochemical, and functional properties. Critical Reviews in Food Science and Nutrition, 40(1), 43-81. https:// doi.org/10.1080/10408690091189266

Lei, M., Wang, J.F., Wang, Y.M., Pang, L., Wang, Y., $\mathrm{Xu}, \mathrm{W}$. and Xue, C.H. (2007). Study of the radioprotective effect of cuttlefish ink on hemopoietic injury. Asia Pacific Journal of Clinical Nutrition, 16 (S1), 239-243.

Li, Z., Wang, B., Chi, C., Gong, Y., Luo, H. and Ding, G. (2013). Influence of average weight on antioxidant and functional properties of cartilage collagen hydrolysates from Sphyrna lewini, Dasyatis akjei and Raja porosa. Food Research International, 51(1), 183-193. https://doi.org/10.1016/ j.foodres.2012.12.031

Lian, P. (2005). Characterization of Squid-Processing Byproduct Hydrolysate and Its Potential as Aquaculture Feed Ingredient. Journal of Agricultural and Food Chemistry, 53(14), 5587-92. https:// doi.org/10.1021/jf050402w

Liaset, B., Lied, E. and Espe, M. (2000). Enzymatic hydrolysis of by-productss from the fish-filleting industry; chemical characterization and nutritional evaluation. Journal of the Science of Food and Agriculture, 80(5), 581-589. https://doi.org/10.1002/ (SICI) 1097-0010(200004)80:5<581::AIDJSFA578>3.0.CO;2-I

Liu, H., Luo, P., Chen, S. and Shang, J. (2011). Effects of Squid Ink on Growth Performance, Antioxidant Functions and Immunity in Growing Broiler Chickens. Asian Australasian Journal of Animal Sciences, 24(12), 1752-1756. https:// doi.org/10.5713/ajas.2011.11128

Lopez-González, A., Tehozol-Sanchez, B., GarcíaIgnacio, H.M., Tlecuitl-Beristain, S., Castro-Corona, A., Hernández-martínez, R., Sanchez-ortega, E., García-dávila, J. and Raquel, L.S. (2003). Antioxidant Activity of Water-Soluble Proteins and Peptides Obtained From the Squid Ink. Retrieved from website: https://smbb.mx/congresos $\% 20 \mathrm{smbb} /$ 
cancun13/TRABAJOS/SMBB/BiotecnologiaMarina/ VII-C04.pdf

Lund, B.M., Baird-Parker, T.C. and Goul, G.W. (2000). The Microbiological Safety and Quality of Foods. Gaithersburg, Maryland, USA: Aspen Publishers.

Lucero, M.T., Farrington, H. and Gilly, W.F. (1994). Quantification of L-dopa and dopamine in squid ink: implications for chemoreception. The Biological Bulletin, 187(1), 55-63. https:// doi.org/10.2307/1542165

Matsue, H., Takaya, Y., Uchisawa, H., Naraoka, T., Sasaki, J. and Ishida, K. (1995). New lights upon squid ink. Bioscience Industry, 53, 31-35.

Menon, I.A. and Haberman, H.F. (1977) Mechanisms of action of melanins. British Journal of Dermatology, 97(1), 109-112. https://doi.org/10.1111/j.13652133.1977.tb15439.x

McConnell, O., Longley, R.E., Koehn, F.E. and Gullo, V.P. (1994). The discovery of natural products with therapeutic potential. In Gullo, V.P. (Ed.) Discovery of Novel Natural Products with Therapeutic Potential., p. 109-174. USA: Elsevier https:// doi.org/10.1016/B978-0-7506-9003-4.50011-3

Mimura, T., Maeda, K., Hariyama, H., Aonuma, S., Satake, M. and Fujita, T. (1982). Studied on biological activities of melanin from marine animals. I. Purification of melanin from Ommastrephes bartrami Lesuel and its inhibitory activity on gastric secretion in rats. Chemical and Pharmacoly Bulletin, 30(4), 1381-1386. https://doi.org/10.1248/ cpb.30.1381

Naraoka, T., Uchisawa, H., Mori, H., Matsue, H., Chiba, S. and Kimura, A. (2003). Purification, characterization and molecular cloning of tyrosinase from the cephalopod mollusk, Illex argentinus. European Journal of Biochemistry, 270(19), 40264038 . https://doi.org/10.1046/j.14321033.2003.03795.x

Nair, J.R., Pillai, D., Joseph, S.M., Gomathi, P., Senan, P.V. and Sherief, P.M. (2011). Cephalopod research and bioactive substances. Indian Journal of GeoMarine-Sciences, 40(1), 13-27.

Neifar, A., Ben Rebah, F., Gargouri, A. and Abdelmouleh, A. (2009). Physicochemical characterization of Sepia officinalis ink and the effects of storage conditions on the coagulation process. Journal of the Marine Biological Association of the United Kingdom, 89(4), 803-807. https://doi.org/10.1017/S0025315408002798

Nisha, N. and Suja, S. (2018). Phyto chemical evaluation and antioxidant activity of methanol extract of
Loligo duvauceli Ink. Journal of Pharmacognosy and Phytochemistry, 7(1), 1764-1767.

Nicomrat, D. and Tharajak, J. (2015). Antimicrobial Effect of Squid Ink on Common Microbial Causing Biofilm Attaching to Silicone. In Yimnirun, R. (Ed.) Applied Mechanics and Materials, Vol. 804, p. 191194. Switzerland, Trans Tech Publications. https:// doi.org/10.4028/www.scientific.net/AMM.804.191

Nielsang, S., Lertsiri, S., Suphantharika, M. and Assavanig, A. (2005). Optimization of enzymatic hydrolysis of fish soluble concentrate by commercial proteases. Journal of Food Engineering, 70(4), 571$578 . \quad$ http://dx.doi.org/10.1016/ j.jfoodeng.2004.10.011

Okuzumi, M. and Fujii, T. (2000). Nutritional and functional properties of squid and cuttlefish., p. 2259. Tokyo, Japan: National Cooperative Association of Squid Processors.

Palumbo, A. (2003). Melanogenesis in the ink gland of Sepia officinalis. Pigment Cell Research, 16(5), 517522. 0749.2003.00080.x

Palumbo, A., Di Cosmo, A. and Gesualdo, I. (1997). A Calcium-Dependent Nitric Oxide Synthase and NMDA R1 Glutamate Receptor in the Ink Gland of Sepia officinalis: A Hint to a Regulatory Role of Nitric Oxide in Melanogenesis? Biochemical and Biophysical Research Communications, 235(2), 429432. https://doi.org/10.1006/bbrc.1997.6734.

Palumbo, A., Gesualdo, I., Di Cosmo, A. and De Martino, L. (1998). The Ink Gland of Sepia officinalis as Biological Model for Investigations of Melanogenesis. In New Developments in Marine Biotechnology, p. 147-149. USA: Springer. https:// doi.org/10.1007/978-1-4757-5983-9_32

Palumbo, A., Poli, A., Di Cosmo, A. and d'Ischia, M. (2000). N-Methyl-d-aspartate Receptor Stimulation Activates Tyrosinase and Promotes Melanin Synthesis in the Ink Gland of the Cuttlefish Sepia officinalis through the Nitric Oxide/cGMP Signal Transduction Pathway A Novel Possible Role for Glutamate as Physiologic Activator of Melanogenesis. Journal of Biological Chemistry, 275(22), 16885-16890. https://doi.org/10.1074/ jbc.M909509199

Panyam, D. and Kilara, A. (1996). Enhancing the functionality of food proteins by enzymatic modification. Trends in Food Science and Technology, 7(4), 120-125. https:// doi.org/10.1016/0924-2244(96)10012-1

Pezzella, A., d'Ischia, M., Napolitaono, A., Palumbo, A. and Prota, G. (1997). An integrated approach to the 
structure of sepia melanin. Evidence for a high proportion of degraded 5,6-dihydroxyindole-2carboxylic acid units in the pigment backbone. Tetrahedron, 53(24), 8281-8286. https:// doi.org/10.1016/S0040-4020(97)00494-8

Qian, C. and Mcclements, D.J. (2011). Formation of nano-emulsions stabilized by model food grade emulsifiers using high-pressure homogenization: factors affecting particle size. Food Hydrocolloids, 25(5), 1000-1008. https://doi.org/10.1016/j. foodhyd.2010.09.017

Quaglia, G.B. and Orban, E. (1990). Influence of enzymatic hydrolysis on structure and emulsifying properties of sardine (Sardina pilchardus) protein hydrolysate. Journal of Food Science, 55(6), 15711573. https://doi.org/10.1111/j.13652621.1990.tb03571.x

Raftani Amiri, Z., Safari, R., Bakhshandeh, T. and Ahmadi Vavsari, F. (2016). Functional properties of fish protein hydrolysates from Cuttlefish (Sepia pharaonis) muscle produced by two commercial enzymes. Iranian Journal of Fisheries Sciences, 15 (4), 1485-1499.

Sasaki, J.I., Ishita, K., Takaya, Y., Uchisawa, H. and Matsue, H. (1997). Anti-tumor activity of squid ink. Journal of Nutritional Science and Vitaminology, 43 (4), 455-461. https://doi.org/10.3177/jnsv.43.455

Shirai, T., Kikuchi, N., Matsuo, S., Inada, H., Suzuki, T. and Hirano, T. (1997). Extractive components of the squid ink. Fisheries Science, 63(5), 772-778. https://doi.org/10.2331/fishsci.63.772

Sila, A., Sayari, N., Balti, R., Martinez-alvarez, O. and Nedjar-arroume, N. (2014). Biochemical and antioxidant properties of peptidic fraction of carotenoproteins generated from shrimp by-products by enzymatic hydrolysis. Food Chemistry, 148, 445452. https://doi.org/10.1016/j.foodchem.2013.05.146

Sorgentini, D.A. and Wagner, J.R. (2002). Comparative study of foaming properties of whey and isolate soybean proteins. Food Research International, 35 (8), 721-729. https://doi.org/10.1016/S0963-9969 (02)00067-4

Su, G., Cui, C., Zheng, L., Yang, B., Ren, J. and Zhao, M. (2012). Isolation and identification of two novel umami and umami-enhancing peptides from peanut hydrolysate by consecutive chromatography and MALDI-TOF/TOF MS. Food Chemistry, 135(12), 479-485. https://doi.org/10.1016/ j.foodchem.2012.04.130

Sundaram, S. (2009). Various uses of cephalopods. Fishing Chimes, 29(8), 23-25.
Wilding, P., Lilliford, P.J. and Regenstain, J.M. (1984). Functional properties of proteins in food. Journal of Chemical Technology and Biotechnology, 34(3), 182 -189. https://doi.org/10.1002/jctb.280340307

Taheri, A., Anvar, S.A.A., Ahari, H. and Fogliano, V. (2013). Comparison of the functional properties of protein hydrolysates from poultry by-products and rainbow trout (Oncorhynchus mykiss) viscera. Iranian Journal of Fisheries Science, 12(1), 154 169.

Takai, M., Yamazaki, K., Kawai, Y., Inove, N. and Shinano, H. (1993). Effect of squid liver skin and ink on microbiological characteristics of 'Ika-Shiokara' during ripening process (part 2). Bulletin of the Japanese Society for the Science of Fish, 59(9), 1617 -1623. https://doi.org/10.2331/suisan.59.1617

Takaya, Y., Uchisawa, H., Hanamatsu, K., Narumi, F., Okuzaki, B. and Matsue, H. (1994). Novel fucose rich glycosaminoglycans from squid ink bearing repeating unit of trisaccharide structure (6GalNAc $\alpha 1$ -3GlcA $31-3$ Fuc $\alpha 1-)$. Biochemical and Biophysical Research Communications, 198(2), 560-567. https:// doi.org/10.1006/bbrc.1994.1082

Vate, N.K. and Benjakul, S. (2013). Antioxidant activity of melanin-free ink from splendid squid (Loligo formosana). International Aquatic Research, 5(1), 4826. https://doi.org/10.1186/2008-6970-5-9

Wang, C.H., Doan, C.T., Nguyen, V.B., Nguyen, A.D. and Wang, S.L. (2019). Reclamation of fishery processing waste: A mini-review. Molecules, 24(12), 2234. https://doi.org/10.3390/molecules24122234

World Health Organization (WHO). (2012). Bulk Density and Tapped Density of Powders. Geneva: WHO.

Zayas, J.F. (Ed.) (1997a). Solubility of proteins. In Functionality of proteins in food, p. 6-75. Berlin: Springer. https://doi.org/10.1007/978-3-642-5911672

Zayas, J.F. (Ed.) (1997b). Emulsifying properties of proteins. In Functionality of proteins in food, p. 134227. Berlin: Springer. https://doi.org/10.1007/978-3642-59116-7 4

Zheng, G.L., Zhang, X.Y., Zhou, Y.G., Meng, Q.C. and Gong, W.G. (2002). Comparison between partial components and trace elements in sepia and squid ink. Chinese Journal of Marine Drugs, 21(3), 12-14.

Zhong, J.P., Wang, G., Shang, J.H., Pan, J.Q., Li, K., Huang, Y. and Liu, H.Z. (2009). Protective effects of squid ink extract towards hemopoietic injuries induced by cyclophosphamine. Marine Drugs, 7(1), 9-18. https://doi.org/10.3390/md7010009 